Article

\title{
Synthesis of High Molecular Weight Vinylphenyl-Con Taining MQ Silicone Resin via Hydrosilylation Reaction
}

\author{
Jianye Ji ${ }^{1}$, Xin Ge ${ }^{2}$, Weijie Liang ${ }^{3}{ }^{\circledR}$, Xiaoyan Pang ${ }^{1}$, Ruoling Liu ${ }^{1}$, Shuyi Wen ${ }^{1}$, Jiaqi Sun ${ }^{1}$, \\ Xunjun Chen ${ }^{1}$ and Jianfang Ge ${ }^{1, *}$ \\ 1 Guangdong Engineering Research Center of Silicone Electronic Fine Chemicals, College of Chemistry and \\ Chemical Engineering, Zhongkai University of Agriculture and Engineering, Guangzhou 510225, China; \\ jijianye@zhku.edu.cn (J.J.); shellypxy@zhku.edu.cn (X.P.); 1rlan@zhku.edu.cn (R.L.); \\ wenshuyi@zhku.edu.cn (S.W.); sunjiaqi@zhku.edu.cn (J.S.); chenxj@zhku.edu.cn (X.C.) \\ 2 School of Materials and Energy, Guangdong University of Technology, Guangzhou 510006, China; \\ gexin@zhku.edu.cn \\ 3 Shaanxi Engineering Laboratory of Graphene New Carbon Materials and Applications, School of Materials \\ Science and Engineering, Northwestern Polytechnical University, Xi'an 710072, China; \\ leungvijer@mail.nwpu.edu.cn \\ * Correspondence: gejianfang@zhku.edu.cn
}

Received: 9 September 2019; Accepted: 20 September 2019; Published: 24 September 2019

\begin{abstract}
To overcome the inherent limitation that the preparation of high molecular weight MQ copolymers $(\mathrm{Mw} \geq 30,000 \mathrm{~g} / \mathrm{mol})$ via the hydrolysis and condensation of solicate salts generally results in an intractable gel, vinylphenyl-containing $M Q$ silicone resin with a high molecular weight was designed and synthesized through the hydrosilylation reaction of vinyl-containing MQ silicone resin and linear poly(diphenylsiloxane) with two terminal $\mathrm{Si}-\mathrm{H}$ bonds. The weight average molecular weight of these modified copolymers reported here is at least $30,000 \mathrm{dal} \cdot \mathrm{mol}^{-1}$. These polymers have favorable thermal stability and a higher refractive index than that of the base resin due to the formation of novel regular macromolecular structures and the introduction of phenyl groups. These inorganic/organic hybrid materials could be used as a potential component for temperature-resistance electronics adhesive, heat-resistant coatings and high-performance liquid silicone rubber. Moreover, the proposed process also provides a possibility to choose higher molecular weight MQ silicones according to application requirements.
\end{abstract}

Keywords: MQ silicone resin; modified; hydrosilylation; high molecular weight

\section{Introduction}

MQ-type silicone resins are polymers consisting of mono-functional siloxane $\left(\mathrm{R}_{3} \mathrm{SiO}_{1 / 2}\right.$, the $\mathrm{M}$ units) and tetra-functional siloxane $\left(\mathrm{SiO}_{4 / 2}\right.$, the $\mathrm{Q}$ units $)[1,2]$, wherein $\mathrm{R}$ is a functional or nonfunctional organic group, such as hydrogen, vinyl, methyl, aryl and some related organic or inorganic groups. These are thus called hydrogen-containing MQ silicone resin, vinyl-containing MQ silicone resin, methyl-containing MQ silicone resin and so on.

Since it was first synthesized by Herbert and his co-workers in the early 1950s [3], MQ-type silicone resins have attracted great attention in commercial applications owing to their special structures and properties. For example, they are used as a tackifier for silicone pressure-sensitive adhesives [4], as silicone hot melt adhesive additives [5], as the reinforced fillers of liquid silicone rubber [6], as the reinforced agent for heat-resistant coatings [7], etc. Silicone pressure-sensitive adhesives using high molecular weight MQ silicone resin (weight average molecular weight, $M w \geq 30,000 \mathrm{~g} / \mathrm{mol}$ ) as a tackifier 
possesses a stronger holding power than that of adhesives using low molecular weight MQ silicone resin (weight average molecular weight, $M w \leq 8000 \mathrm{~g} / \mathrm{mol}$ ) with a similar structure [8]. In addition, MQ silicone resin is an essential part of silicone hot melt adhesive [9], as it can effectively improve the mechanical and adhesive properties. Generally, high molecular weight MQ silicone resin has a more obvious improving effect than low molecular weight silicone resin [7]. Therefore, it makes sense to prepare high molecular weight MQ silicone resin. However, a polymer with greater molecular weight does not always cause a better application result. For example, using an MQ resin with an exorbitant molecular weight as a tackifier for silicone pressure-sensitive adhesive will lead to the decrease of the initial adhesion of the adhesive. This does not influence the importance of this polymer, however, because it can be possible to choose higher molecular weight MQ silicones according to application requirements.

MQ silicone resins are frequently synthesized through hydrolysis/condensation reactions of tetraethoxysilane [10-12] or silicate salts [13,14], followed by end capping reactions with monofunctional siloxane. Their weight average molecular weight and number average molecular weight have been controlled to about 30,000 and $7000 \mathrm{~g} / \mathrm{mol}$ separately for the inherent limitation of this reaction, as attempts to synthesize higher molecular weight copolymers by reducing the value of the $\mathrm{M} / \mathrm{Q}$ ratio have usually resulted in the formation of an intractable gel [15]. Huang [16] prepared MQ silicone resins with a number average molecular weight of about $6000 \mathrm{~g} / \mathrm{mol}$ through the hydrolytic condensation of ethyl polysilicate and hexamethyldisiloxane in 1998. Xu [17] prepared methylphenyl-modified MQ silicone resins with a number average molecular weight of about $7000 \mathrm{~g} / \mathrm{mol}$ through co-hydrolysis and the condensation polymerization of sodium silicate, hexamethyldisiloxane (MM),1,1,3,3-tetramethyl-1,3-divinyldisiloxane and methyldiphenylethoxy silane in 2013. Though Flagg [18] prepared MQ silicone resins with a weight average molecular weight of more than $30,000 \mathrm{~g} / \mathrm{mol}$, there remained problems with difficult-to-avoid sol growth and complete gel formation. Meanwhile, the weight average molecular weight of MQ resins has not yet exceeded 100,000 g/mol.

The introduction of phenyl can improve the heat resistance and refractive index of MQ silicone resin, which further enlarges its application possibilities [19]. To address the abovementioned issues, an approach to synthesize high molecular weight phenyl-modified MQ silicone resin (VPMQ) through the hydrosilylation reaction of low molecular weight vinyl-containing MQ silicone resin (VMQ) and linear poly(diphenylsiloxane) with two terminal $\mathrm{Si}-\mathrm{H}$ bonds (PDPS) was reported. Simultaneously, a series of different molecular weight VPMQ polymers were prepared by changing the molar ratio of $\mathrm{Si}-\mathrm{H} / \mathrm{Si}-\mathrm{CH}=\mathrm{CH}_{2}$ under appropriate conditions. The structure, molecular weight, optical properties and thermal stability properties of these silicone resins were investigated. Overall, this studies aimed to obtain VPMQ material with a high molecular weight and good optical and thermal stability, thus further improving its application value.

\section{Materials and Methods}

\subsection{Materials}

Tetraethyl orthosilicate (TEOS, AR), 1,1,3,3-tetramethyl divinyl disiloxane (TMDVS, AR) and hexamethyldisiloxane (MM, AR) were purchased from Shanghai Hansi Chemical industry Co., Ltd. (Shanghai, China). Hydrochloric acid ( $\mathrm{HCl}, \mathrm{AR})$, ethanol $\left(\mathrm{C}_{2} \mathrm{H}_{5} \mathrm{OH}, \mathrm{AR}\right)$ and toluene $(98 \mathrm{wt} \%$, AR) were provided by Tianjin Baishi Chemical industry Co., Ltd. (Tianjin, China). Linear poly(diphenylsiloxane) with two terminal $\mathrm{Si}-\mathrm{H}$ bonds (PDPS, hydrogen content: $0.25 \mathrm{wt} \%$, AR) was supplied by Iota Silicone Oil Co., Ltd. (Anhui, China). Chloroplatinic acid $\left(\mathrm{H}_{2} \mathrm{PtCl}_{6}, 5000 \mathrm{mg} / \mathrm{Kg}\right.$, AR) was purchased from Tianjin Maisike Chemical Industry Co., Ltd. (Tianjin, China). Carbon tetrachloride $\left(\mathrm{CCl}_{4}, \geq 95 \mathrm{wt} \%\right.$, $\mathrm{AR})$, iodine bromide (IBr, $98 \mathrm{wt} \%, \mathrm{AR})$, potassium iodide (KI, $100 \mathrm{~g} / \mathrm{L}, \mathrm{AR})$, sodium thiosulfate $\left(\mathrm{Na}_{2} \mathrm{~S}_{2} \mathrm{O}_{3}, 0.1 \mathrm{~mol} / \mathrm{L}, \mathrm{AR}\right)$ and starch solution $(1.0 \mathrm{wt} \%, \mathrm{AR})$ were purchased from Shanghai Aladdin Bio-Chem Technology Co., Ltd. (Shanghai, China). 


\subsection{Synthesis of the VMQ}

The VMQ was prepared by the hydrolysis/condensation reactions of TEOS, TMDVS and MM, according to a literature procedure reported by Xiang et al. with a small amendment [20]. Distilled water $(40.0 \mathrm{~mL}), \mathrm{HCl}(6.0 \mathrm{~mL})$, toluene $(50.0 \mathrm{~mL})$, ethanol $(10.0 \mathrm{~mL})$, TMDVS $(8.19 \mathrm{~g}, 0.05 \mathrm{~mol})$ and $\mathrm{MM}$ ( $37.3 \mathrm{~g}, 0.2 \mathrm{~mol}$ ) were added to a $500 \mathrm{~mL}$ three-necked flask. The mixture was stirred for $30 \mathrm{~min}$ at room temperature and then the TEOS $(104.2 \mathrm{~g}, 0.5 \mathrm{~mol})$ was added to the flask drop by drop. Stirring continued at $60^{\circ} \mathrm{C}$ for $3 \mathrm{~h}$. After that, $100 \mathrm{~mL}$ toluene was used to extract the products and deionized water was used to wash the products until $\mathrm{pH}=7$ was reached. Finally, the polymer-toluene solution was distilled at $110^{\circ} \mathrm{C}$ for $1 \mathrm{~h}$ to obtain the VMQ polymers. The mass fraction of vinyl of the VMQ was measured and the results showed a vinyl content of $1.8 \%$.

\subsection{Synthesis of the VPMQ}

Taking the synthesis of VPMQ- 1 as an example: VMQ $(30.0 \mathrm{~g})$, toluene $(6.0 \mathrm{~mL})$, PDPS $(1.60 \mathrm{~g})$ and the hydrosilylation catalyst $\mathrm{H}_{2} \mathrm{PtCI}_{6}(0.06 \mathrm{~g})$ were added to a $250 \mathrm{~mL}$ three-necked flask. The mixture was stirred for $5 \mathrm{~h}$ at $70^{\circ} \mathrm{C}$; then, the toluene and low molecular byproducts were distilled at $110{ }^{\circ} \mathrm{C}$ for $2 \mathrm{~h}$ to obtain the VPMQ polymer (Figure 1, Table 1).
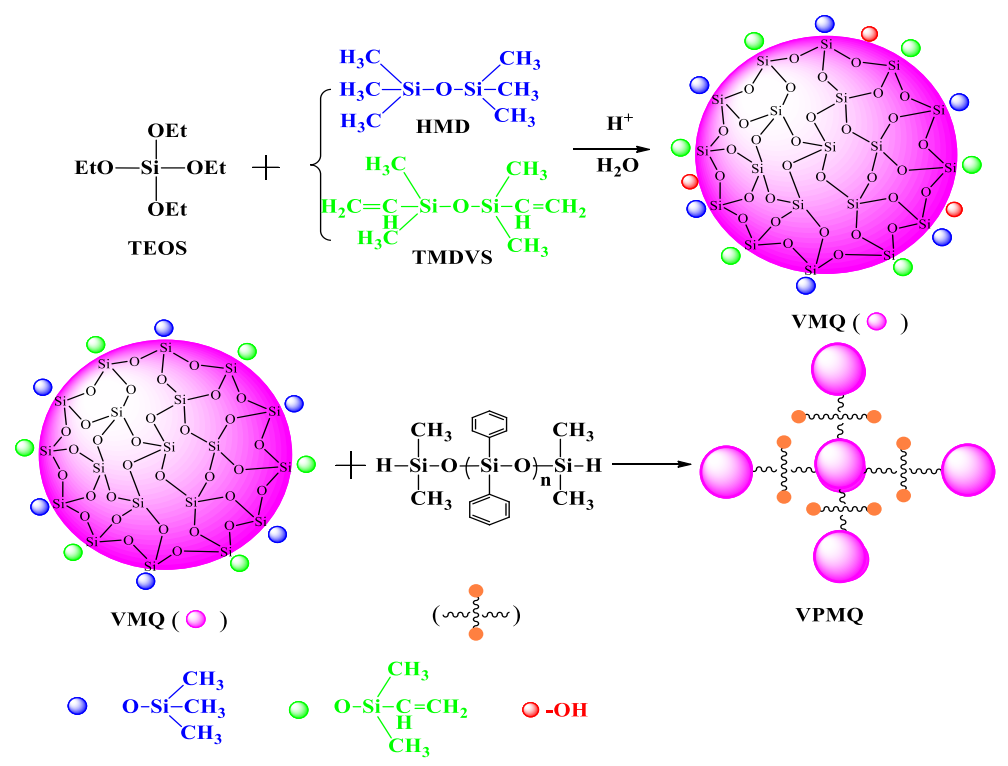

Figure 1. Synthesis routine of the VPMQ.

\subsection{Characterizations and Measurements}

Content of vinyl groups in the VMQ: The mass fraction of vinyl groups in the VMQ was measured by iodimetry according to a previously reported procedure [21]. First, the VMQ sample was dissolved into a $250 \mathrm{~mL}$ iodine flask containing $20 \mathrm{~mL}$ of $\mathrm{CCl}_{4}$ solution. This was shaken evenly. Second, $10 \mathrm{~mL}$ of IBr was added to the iodine flask, which was shaken evenly again. The reaction was allowed to continue in the dark for $1 \mathrm{~h}$. Thirdly, $5 \mathrm{~mL}$ of KI solution was added to the iodine flask, which was shaken for about $5 \mathrm{~min}$. After that, $40 \mathrm{~mL}$ of distilled water was added. Fourth, the solution was titrated with $0.1 \mathrm{~mol} / \mathrm{L}$ of $\mathrm{Na}_{2} \mathrm{~S}_{2} \mathrm{O}_{3}$ until it became light yellow. Then, $2.0 \mathrm{~mL}$ of a starch solution was added. The solution continued to be titrated until the blue coloration disappeared. The mass fraction of vinyl groups in the VMQ was determined by the following equation:

$$
\omega=\frac{27 \times 0.5 \times 0.001 \times C_{\mathrm{Na}_{2} \mathrm{~S}_{2} \mathrm{O}_{3}} \times\left(V_{0}-V_{1}\right)}{M}
$$


where $\omega$ is the mass fraction of the vinyl groups in the VMQ (\%); $\mathrm{C}_{\mathrm{Na}_{2} \mathrm{~S}_{2} \mathrm{O}_{3}}$ is the concentration of $\mathrm{Na}_{2} \mathrm{~S}_{2} \mathrm{O}_{3}(\mathrm{~mol} / \mathrm{L}) ; V_{0}$ is the volume of $\mathrm{Na}_{2} \mathrm{~S}_{2} \mathrm{O}_{3}$ consumed by the blank experiment; $V_{1}$ is the volume of $\mathrm{Na}_{2} \mathrm{~S}_{2} \mathrm{O}_{3}$ consumed by the experimental group.

Physical state in toluene: About $1.00 \mathrm{~g}$ of every polymer sample was put into $10 \mu \mathrm{L}$ of toluene solvent to observe its physical state in toluene, and the solubility or dispersibility of the polymers was evaluated by observing the appearance of the mixture.

FT-IR: The structure of VMQ and VPMQ samples was characterized by VERTEX70 Fourier transform infrared (FT-IR) spectra (Shimadzu, Japan) combined with the HF-7 detachable liquid pool (Bruker, Karlsruhe, Germany) with a capacity of $1 \mathrm{~mL}$. All the samples were formulated with a mass concentration of $5 \mathrm{wt} \%$ by dissolving $0.20 \mathrm{~g}$ of the samples into $39.80 \mathrm{~g}$ of $\mathrm{CCl}_{4}$ solution. Every sample was scanned from 400 to $4000 \mathrm{~cm}^{-1}$ and averaged over 16 times.

${ }^{1} \mathrm{H}-\mathrm{NMR}$ : The structure of the VMQ and VPMQs was characterized at $25{ }^{\circ} \mathrm{C}$ with an Av500 Hydrogen Nuclear Magnetic Resonance Spectrometer (Bruker, Germany) at a frequency of $500 \mathrm{MHz}$. Deuterated chloroform $\left(\mathrm{CDCl}_{3}\right)$ was used as the solvent and tetramethylsilane (TMS) as an internal standard.

${ }^{29} \mathrm{Si}$ NMR: The ${ }^{29} \mathrm{Si}$ NMR analysis of the VMQ and VPMQ samples was carried out on Bruker AVANCE AV $400 \mathrm{MHz}$ spectrometer (Bruker, Germany) at room temperature, and $\mathrm{CDCl}_{3}$ was used as a solvent.

Gel permeation chromatography (GPC): Molecular weights and molecular weight distributions of all the samples were determined by GPC using an Angilent 1260 infinity LC system (Angilent, America) equipped with two PLgel MixedC columns and one PLgel Mixed-D column as well as a refractive index detector. The operation was performed at $25 \pm 1{ }^{\circ} \mathrm{C}$, using HPLC grade THF as the eluent with a flow rate of $1 \mathrm{~mL} / \mathrm{min}$. Polystyrenes were used as the molecular weight standards.

Differential scanning calorimetry (DSC): The Glass translation temperature (Tg) of the samples were investigated by Q2000 Differential scanning calorimetry (TA Instruments, Wilmington, American). The temperature was increased from $-100{ }^{\circ} \mathrm{C}$ to $240{ }^{\circ} \mathrm{C}$ at a heating rate of $10^{\circ} \mathrm{C} / \mathrm{min}$.

Thermogravimetric analysis (TGA): Thermogravimetric analysis measurement was carried out on a Mettler Toledo TG thermal analyzer (Mettler Toledo AG, Columbus, OH, USA) at a flow rate of $20 \mathrm{~mL} / \mathrm{min}$ in nitrogen. The samples were heated from 40 to $800{ }^{\circ} \mathrm{C}$ at a rate of $10^{\circ} \mathrm{C} / \mathrm{min}$.

Refractive index measurement: The refractive indexes of the samples were measured using a 2WA-J Abbe refractometer (Shanghai CSOIF Co., Ltd., Shanghai, China). Before measuring, the samples were dissolved in carbon tetrachloride.

\section{Results and Discussion}

\subsection{Structural Analysis}

The molecular weight of MQ silicone resin is mainly determined by the molar ratio of $\mathrm{M}$ units to $Q$ units [20]. In the experiment, we attempted to directly prepare high molecular weight MQ silicone resin through the hydrolysis/condensation reactions of TEOS ( $\mathrm{Q}$ units), TMDVS ( ${ }^{\mathrm{vi}} \mathrm{M}$ units) and MM ( $M$ units) by decreasing the ratio of $M$ units to $Q$ units. Unfortunately, this attempt failed. This was because too small of a molar ratio of $\mathrm{M} / \mathrm{Q}$ causes the formation of highly reactive $\mathrm{Q}$ units, which are difficult to control and inevitably produce a gel [22]. On the contrary, MQ silicone resins with high molecular weight prepared via a hydrosilylation reaction of low molecular weight MQ silicone resin and PDPS are easy to control due to their mild reaction condition. Meanwhile, PDPS was simply used as a linear molecular bridge to link the low molecular weight of VMQ to make the high molecular weight VPMQ polymers in this reaction; it has almost no effect on the ratio of M/Q unit in MQ silicone. Therefore, it increases the molecular weight of MQ silicone resin and does not result in gelation at an appropriate addition amount.

The content of vinyl groups, average molecular weight and polydispersity index of VMQ were measured first. The results showed that the mass fraction of vinyl groups in VMQ was $1.8 \%$, while the 
average molecular weight and polydispersity index values were $4801 \mathrm{dal} / \mathrm{mol}$ and 1.87 , respectively. Then, VPMQ with high molecular weight was synthesized through the hydrosilylation reaction of VMQ and PDPS. These novel polymers have structures similar but not identical to MDQ silicone resin, because difunctional siloxanes $\left(\mathrm{D}, \mathrm{R}_{2} \mathrm{SiO}_{2 / 2}\right)$ were introduced into the polymer but not all the silicon atoms are connected by $\mathrm{Si}-\mathrm{O}-\mathrm{Si}$ bonds. Even so, such polymers can still be considered as MQ-type silicone resins because less than $20 \%$ of the resin molecules are comprised of $D$ units [23]. To analyze the structure and properties of these copolymers, a series of VPMQ samples was synthesized by changing the molar ratio of $\mathrm{Si}-\mathrm{H} / \mathrm{Si}-\mathrm{CH}=\mathrm{CH}_{2}$. The amount of each feed material is listed in Table 1. As can be seen, the physical state of these polymers changed from a viscous liquid to a semisolid when moving from VPMQ-1 to VPMQ-5, and the physical state of their dispersions in toluene varied from a clear liquid to a gel when moving from VPMQ-1 to VPMQ-5. The presence of the clear liquid state in toluene solvent indicates that the VPMQ materials have good dispersibility, while the presence of the gelatinous liquid state indicates that the polymer has poor dispersibility and little application value.

Table 1. The formulations of VPMQ polymers.

\begin{tabular}{cccccccc}
\hline Entry & $\begin{array}{c}\mathbf{S i}-\mathbf{H} / \\
\mathbf{S i}-\mathbf{C H}=\mathbf{C H}_{\mathbf{2}}\end{array}$ & $\begin{array}{c}\text { VMQ } \\
(\mathbf{g})\end{array}$ & $\begin{array}{c}\text { PDPS } \\
\mathbf{( g )}\end{array}$ & $\begin{array}{c}\mathbf{H}_{\mathbf{2}} \mathbf{P t C I}_{\mathbf{6}} \\
\mathbf{( g )}\end{array}$ & $\begin{array}{c}\text { Toluene } \\
\mathbf{( g )}\end{array}$ & Physical State & $\begin{array}{c}\text { Dispersion } \\
\text { in Toluene }\end{array}$ \\
\hline VPMQ-1 & $0.2 / 1$ & 30.00 & 1.60 & 0.06 & 6.0 & viscous liquid & clear \\
VPMQ-2 & $0.4 / 1$ & 30.00 & 3.20 & 0.06 & 6.0 & viscous liquid & clear \\
VPMQ-3 & $0.6 / 1$ & 30.00 & 4.80 & 0.06 & 6.0 & viscous liquid & clear \\
VPMQ-4 & $0.8 / 1$ & 30.00 & 6.00 & 0.07 & 6.0 & semisolid & clear \\
VPMQ-5 & $1.0 / 1$ & 30.00 & 7.20 & 0.07 & 6.0 & semisolid & gelatinous \\
\hline
\end{tabular}

The FT-IR spectra of VMQ, PDPS and VPMQ are shown in Figure 2a. In the curve of the VMQ, the strong absorption peak at $3450 \mathrm{~cm}^{-1}$ is assigned to the $\mathrm{H}$-bonded silanol ( $\left.\mathrm{Si}-\mathrm{OH}\right)$ group [24]. The peaks at 2960 and $2910 \mathrm{~cm}^{-1}$ are attributed to the stretching vibration absorption of $\mathrm{C}-\mathrm{H}$ in $-\mathrm{CH}_{3}$, and the peak at $1260 \mathrm{~cm}^{-1}$ is ascribed to the scissoring vibration absorption of $\mathrm{Si}-\mathrm{CH}_{3}$. The peaks at 1600 and $1410 \mathrm{~cm}^{-1}$ correspond to the stretch vibration absorption of $\mathrm{C}-\mathrm{H}$ in $\mathrm{Si}-\mathrm{CH}=\mathrm{CH}_{2}$. In addition, the broad absorption peak at $1100-1080 \mathrm{~cm}^{-1}$ is attributed to the stretching vibration absorption of Si-O-Si [25,26]. In the curve of PDPS, the peak at about $3080 \mathrm{~cm}^{-1}$ is assigned to the stretching vibration of the $\mathrm{C}-\mathrm{H}$ group in $\mathrm{Si}-\mathrm{C}_{6} \mathrm{H}_{5}$, and the sharp peaks at 1591 and $1430 \mathrm{~cm}^{-1}$ correspond to the $\mathrm{C}-\mathrm{C}$ stretching vibration of $\mathrm{Si}-\mathrm{C}_{6} \mathrm{H}_{5}$. Simultaneously, the characteristic peaks at 800,756 and $702 \mathrm{~cm}^{-1}$ are associated with the ring deformation vibration and $\mathrm{C}-\mathrm{H}$ deformation vibration of the phenyl group, respectively. Moreover, it is relatively easy to observe the strong signal of $\mathrm{Si}-\mathrm{H}$ at $2134 \mathrm{~cm}^{-1}$. In terms of the VPMQ, the characteristic absorption peaks of the $\mathrm{C}-\mathrm{H}$ group on $\mathrm{Si}-\mathrm{C}_{6} \mathrm{H}_{5}$ also appear at 3080, 800, 756 and $702 \mathrm{~cm}^{-1}$ [27]. Furthermore, the symmetric stretching vibrations of $\mathrm{C}-\mathrm{H}$ on Si- $\mathrm{CH}_{2}-\mathrm{CH}_{2}-\mathrm{Si}$ bridges formed during the hydrosilylation reaction appear at $2870 \mathrm{~cm}^{-1}$ [28], and the characteristic absorption peak at $1010 \mathrm{~cm}^{-1}$ attributed to Si-O-Si introduced by PDPS can be seen. Moreover, the characteristic absorption peak of $\mathrm{Si}-\mathrm{CH}=\mathrm{CH}_{2}$ at $1600 \mathrm{~cm}^{-1}$ is significantly weakened, and the absorption peak of $\mathrm{Si}-\mathrm{H}$ at $2134 \mathrm{~cm}^{-1}$ is absent. Based on the above analysis, it can be concluded that the VPMQ polymer was synthesized successfully.

In addition, to further investigate the extent of the reaction, the characteristic absorption peak at $1600 \mathrm{~cm}^{-1}$ for $\mathrm{Si}-\mathrm{CH}=\mathrm{CH}_{2}$ on VMQ and VPMQ samples was mainly observed. The results show that area of the absorption peaks were in the order of VMQ $>$ VPMQ-1 > VPMQ-2 > VPMQ-3 > VPMQ-4. This is because more $\mathrm{Si}-\mathrm{CH}=\mathrm{CH}_{2}$ was consumed with increasing additions of PDPS. Meanwhile, we have also pay attention to the characteristic peak at $2134 \mathrm{~cm}^{-1}$ for the $\mathrm{Si}-\mathrm{H}$ group. Fortunately, the characteristic absorption peak of the $\mathrm{Si}-\mathrm{H}$ bond was not found in all the samples, indicating that the $\mathrm{Si}-\mathrm{H}$ group on the PDPS was consumed completely, and there was no free PDPS in the reaction system.

The structures of VMQ, PDPS and VPMQ were confirmed by ${ }^{1} \mathrm{H}$ NMR spectroscopy, as shown in Figure 3. The structures of the samples are shown in Figure $3 a, b$, revealing the ${ }^{1} \mathrm{H}$ NMR spectrum of 
the polymers. Here, the characteristic peaks at $0 \sim 0.18$ and $5.56 \sim 6.07 \mathrm{ppm}$ are assigned to the silicon methyl and vinyl groups, respectively, for $\mathrm{M}$ units in the VMQ. The characteristic signals located about $2.63 \mathrm{ppm}$ are attributed to the proton peaks of silicon-hydroxyl. For PDPS, the signal at about $0.12 \mathrm{ppm}$ also corresponds to the protons on silicon-methyl, while the peak at about $4.51 \mathrm{ppm}$ is assigned to the $\mathrm{Si}-\mathrm{H}$ group. The signals at about 7.50, 7.25 and $7.05 \mathrm{ppm}$ are related to the protons of the benzene of PDPS. In the ${ }^{1} \mathrm{H}$ NMR spectrum of VPMQ, we observed the chemical shifts of proton peaks of $-\mathrm{CH}_{3}$ and $\mathrm{Si}-\mathrm{CH}=\mathrm{CH}_{2}$ groups. The strong signal located at $0.65 \sim 0.8 \mathrm{ppm}$ corresponds to the protons of the $\mathrm{Si}-\mathrm{CH}_{2} \mathrm{CH}_{2}$ group. The signals located at $0.84 \sim 1.08$ and $1.72 \sim 1.82 \mathrm{ppm}$ for the protons of the $\mathrm{C}-\mathrm{CH}_{3}$ and $\mathrm{C}-\mathrm{H}$ group can also be seen. Moreover, the characteristic signals located at 7.50, 7.25 and $7.05 \mathrm{ppm}$ belonging to the protons of phenyl region appear as well. This analysis indicated that VPMQ was synthesized successfully through Markownikow and Anti-Markovnikow addition reactions, and the addition reaction was carried out a result of both a small amount of $\alpha$ and primarily $\beta$ addition products [29].
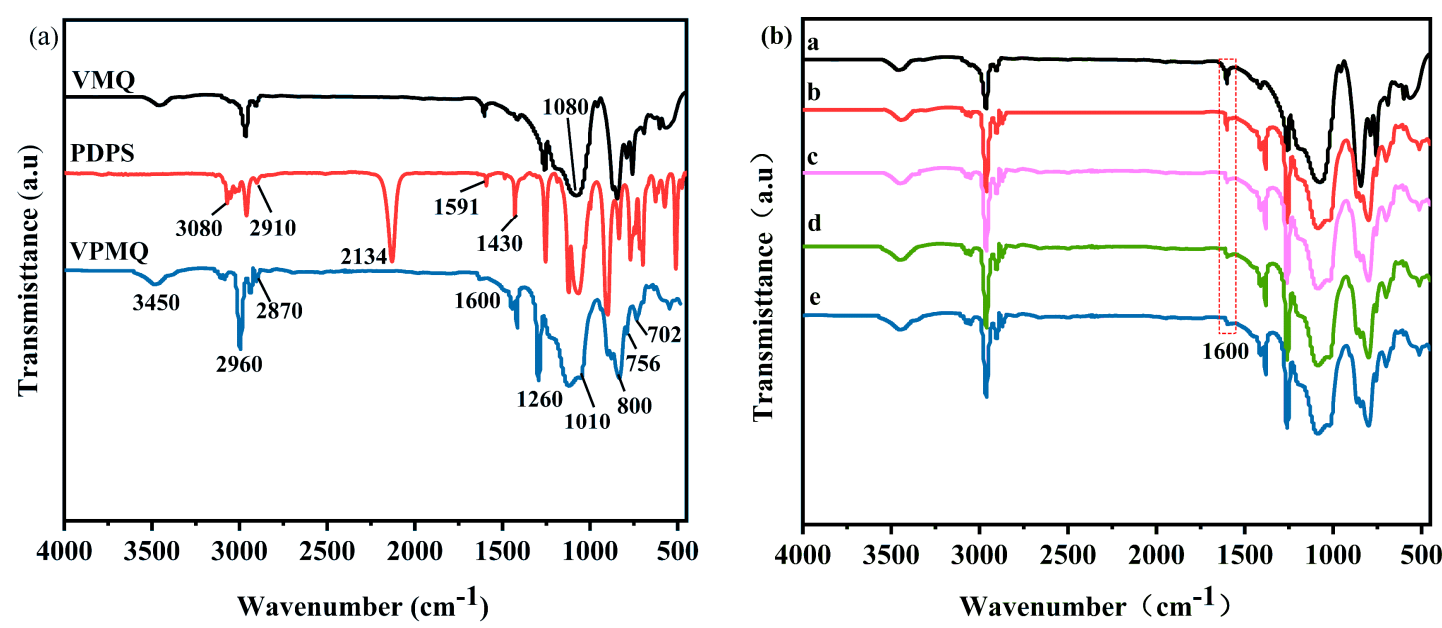

Figure 2. (a) Infrared spectra of VMQ, PDPS and VPMQ; (b) infrared spectra of VMQ and VPMQ series. (a-e) VMQ, VPMQ-1, VPMQ-2, VPMQ-3 and VPMQ-4, respectively.

(a)

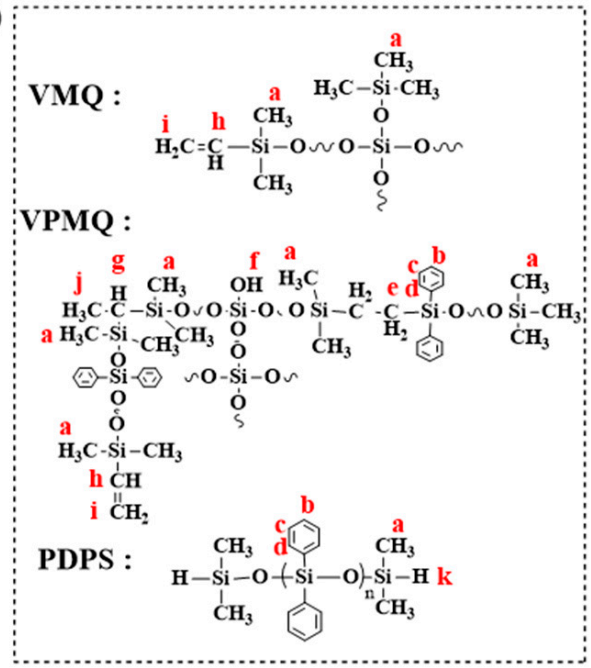

(b)

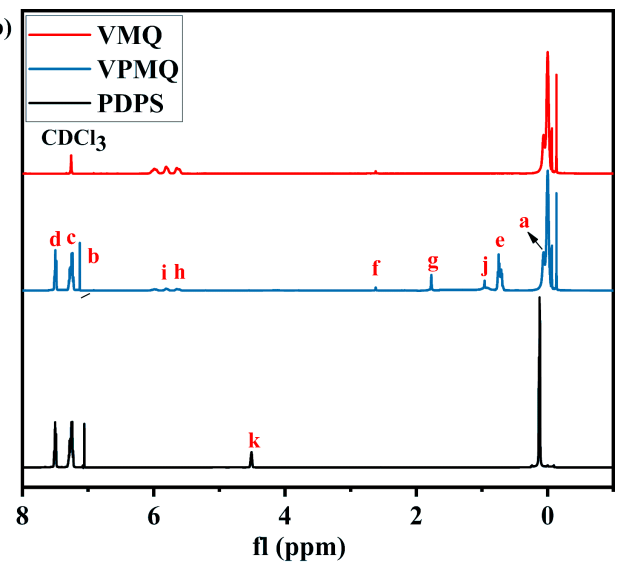

Figure 3. ${ }^{1} \mathrm{H}$ NMR spectrum of VMQ, VPMQ and PDPS: (a) Molecular formula of VMQ, VPMQ and PDPS; (b) ${ }^{1} \mathrm{H}$ NMR spectrum of VMQ, VPMQ-4 and PDPS.

${ }^{29} \mathrm{Si}$ NMR spectroscopy is a useful tool to characterize the skeleton structure of organosilicon polymers [30]. As shown in Figure 4a,b, the structures of PDPS, VMQ and VPMQ series were further 
confirmed by ${ }^{29} \mathrm{Si}$ NMR spectra. In the spectra of PDPS, clusters of signal peaks at about -5.06 and $-21.24 \mathrm{ppm}$ are related to the ${ }^{\mathrm{H}} \mathrm{M}\left(\mathrm{HR}_{2} \mathrm{SiO}_{1 / 2}\right)$ and $\mathrm{D}\left(\mathrm{Ph}_{2} \mathrm{SiO}_{2 / 2}\right)$ units. Similarly, there are $\mathrm{Q}\left(\mathrm{SiO}_{4 / 2}\right)$, ${ }^{\mathrm{Vi}} \mathrm{M}\left(\mathrm{R}_{1} \mathrm{R}_{2} \mathrm{SiO}_{1 / 2}\right)$ and $\mathrm{M}\left(\mathrm{R}_{3} \mathrm{SiO}_{1 / 2}\right)$ units contained in the skeleton structure of the VMQ silicone resin, and it was found that their chemical shifts are located at $-111.07,-2.41$ and $11.98 \mathrm{ppm}$, respectively [3]. In the spectra of VPMQ, the chemical shifts located at -21.24 and $-2.41 \mathrm{ppm}$ corresponding to $\mathrm{D}\left(\mathrm{Ph}_{2} \mathrm{SiO}_{2 / 2}\right)$ and ${ }^{\mathrm{Vi}} \mathrm{M}\left(\mathrm{R}_{1} \mathrm{R}_{2} \mathrm{SiO}_{1 / 2}\right)$ units were also noted, in addition to the characteristic signals at -111.07 and $11.98 \mathrm{ppm}$ for $\mathrm{Q}$ and $\mathrm{M}$ units. This indicates that the VPMQ polymer contains a $\mathrm{D}$ $\left(\mathrm{Ph}_{2} \mathrm{SiO}_{2 / 2}\right)$ unit introduced by linear PDPS, while still retaining a small amount of unreacted vinyl groups. Meanwhile, no chemical shifts were found at about $-5.06 \mathrm{ppm}$ for ${ }^{\mathrm{H}} \mathrm{M}\left(\mathrm{HR}_{2} \mathrm{SiO}_{1 / 2}\right)$ units, while chemical shifts near 6.02 7.98 ppm corresponding to silicon-methine and silicon-methylene in $\mathrm{M}$ units are visible. This shows that VPMQ was prepared successfully through hydrosilylation, and that $\alpha$ and $\beta$ addition products are contained in VPMQ polymers. Unfortunately, we failed to recognize which type of addition products were dominant from the ${ }^{29} \mathrm{Si}$ NMR spectra of VPMQ. Still, because the steric hindrance of the $\alpha$ addition would be much larger than that of the $\beta$ addition, the reaction is commonly obtained a result of a trace amount of $\alpha$ addition products and primarily $\beta$ addition products, as confirmed via ${ }^{1} \mathrm{H}$ NMR spectroscopy [31]. Moreover, the reaction state of VPMQ polymers with increasing molar ratios of $\mathrm{Si}-\mathrm{H} / \mathrm{Si}-\mathrm{CH}=\mathrm{CH}_{2}$ was also investigated by observing the intensity of absorption bands located at -111.07 and $-2.41 \mathrm{ppm}$ from VPMQ-1 to VPMQ-4. As shown in Figure $4 \mathrm{~b}$, it was found that the area of the $Q$ unit region at $-111.07 \mathrm{ppm}$ increased gradually from VPMQ-1 to VPMQ-4, but the area of ${ }^{\mathrm{Vi}} \mathrm{M}$ units at $-2.41 \mathrm{ppm}$ decreased gradually. These observations indicate that with the increasing molar ratio of $\mathrm{Si}-\mathrm{H} / \mathrm{Si}-\mathrm{CH}=\mathrm{CH}_{2}$ (from VPMQ-1 to VPMQ-4), more and more vinyl groups are consumed, and a novel MQ silicone resin with a larger molecular structure can be prepared.
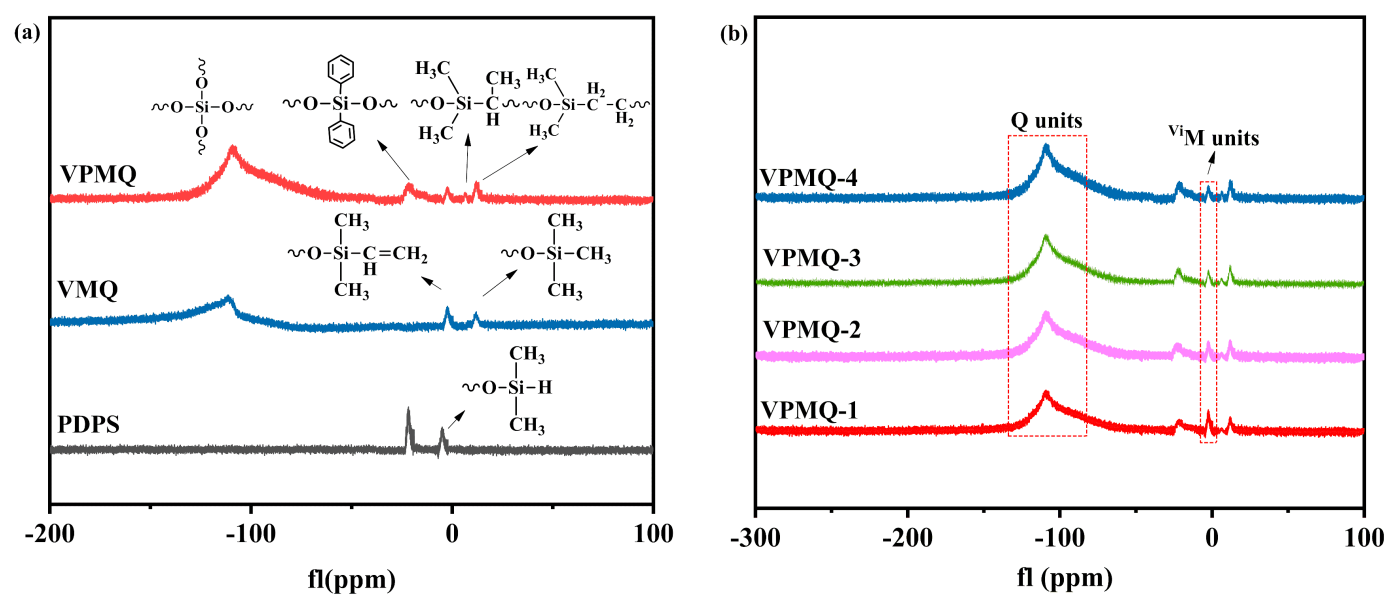

Figure 4. (a) ${ }^{29} \mathrm{Si}$ NMR spectra of VMQ, VPMQ and PDPS. (b) ${ }^{29} \mathrm{Si}$ NMR comparison of VPMQ samples.

The molecular weights of PDPS, VMQ and VPMQ samples were determined by GPC, as listed in Table 2. The weight average molecular weights (Mw) of PDPS, VMQ, VPMQ-1, VPMQ-2, VPMQ-3 and VPMQ-4 were 800, 4801, 31099, 77321, 97199 and $391817 \mathrm{dal} \cdot \mathrm{mol}^{-1}$, respectively. The number average molecular weights (Mn) of PDPS, VMQ, VPMQ-1, VPMQ-2, VPMQ-3 and VPMQ-4 were 512, 2562, $17357,29420,37585$ and $285494 \mathrm{dal} \cdot \mathrm{mol}^{-1}$, with proper polydispersity indexes of 1.56, 1.87, 1.79, 2.68, 1.43 and 1.37, respectively. As can be seen, the molecular weights of VPMQ increased quickly with the increase of the molar ratio of $\mathrm{Si}-\mathrm{H} / \mathrm{Si}-\mathrm{CH}=\mathrm{CH}_{2}$, which can be attributed to the hydrosilylation reaction of VMQ and PDPS, in which PDPS was served as a bridge to achieving a high molecular weight. Note that VPMQ became gelatinous when the molar ratio value of $\mathrm{Si}-\mathrm{H} / \mathrm{Si}-\mathrm{CH}=\mathrm{CH}_{2}$ reached 1 (shown in Table 2). This can be attributed to the occurrence of a cross-linking reaction when the number of $\mathrm{Si}-\mathrm{H}$ groups is excessive. Therefore, it is necessary to control a proper molar ratio value of $\mathrm{Si}-\mathrm{H} / \mathrm{Si}-\mathrm{CH}=\mathrm{CH}_{2}$ to obtain high molecular weight and dispersible VPMQ polymers. 
Table 2. The gel permeation chromatography (GPC) data and refractive index of VPMQ samples.

\begin{tabular}{ccccc}
\hline Entry & $\begin{array}{c}\boldsymbol{M w} \\
\left(\mathbf{d a l} \cdot \mathbf{m o l}^{-\mathbf{1}} \mathbf{)}\right.\end{array}$ & $\begin{array}{c}\boldsymbol{M n} \\
\left(\mathbf{d a l} \cdot \mathbf{m o l}^{-\mathbf{1}} \mathbf{)}\right.\end{array}$ & $\mathbf{M w / M n}$ & $\boldsymbol{n}_{\boldsymbol{D}}^{25}$ \\
\hline PDPS & 800 & 512 & 1.56 & 1.5440 \\
\hline VMQ & 4801 & 2562 & 1.87 & 1.4840 \\
VPMQ-1 & 31,099 & 17,357 & 1.79 & 1.4850 \\
VPMQ-2 & 77,321 & 28,902 & 2.68 & 1.4889 \\
VPMQ-3 & 197,199 & 137,585 & 1.43 & 1.4890 \\
VPMQ-4 & 391,817 & 285,494 & 1.37 & 1.4994 \\
\hline
\end{tabular}

\subsection{Refractive Index Analysis}

The refractive index of silicone resin is an interesting reference for the polymers used in applications with high optical requirements. The refractive index values of PDPS, VMQ and VPMQ series are also listed in Table 3. It was found that PDPS possessed the highest refractive index value (1.5440 for PDPS). Simultaneously, the refractive index of the VPMQ series was higher than that of VMQ, in the order of VPMQ-1 < VPMQ-2 < VPMQ-3 < VPMQ-4. This indicated that PDPS has good compatibility with VMQ. The refractive index values of the VPMQ series increased from 1.4850 to 1.4994 as the molar ratio value of $\mathrm{Si}-\mathrm{H} / \mathrm{Si}-\mathrm{CH}=\mathrm{CH}_{2}$ increased from $0.2 / 1$ to $0.8 / 1$. This could be due to the introduction of the phenyl group, which has a refractive index as high as 25.46 , which is barely below that of naphthyl in all groups yet discovered [32]. In terms of phenyl silicone resin polymers, their refractive index value is mainly determined by their phenyl contents, and remains almost unaffected by their structure [33]. Among all the VPMQ polymers, VPMQ-4 possessed the highest refractive index value (1.4994), as it contained the highest content of phenyl groups. This means that VPMQ-4 has greater application potential in the applications of optical encapsulation and bonding.

Table 3. The characteristic degradative data of VMQ and VPMQ samples.

\begin{tabular}{ccccc}
\hline Entry & $\boldsymbol{T}_{\max }\left({ }^{\circ} \mathbf{C}\right)$ & $\boldsymbol{T}_{\mathbf{5}}\left({ }^{\circ} \mathbf{C}\right)$ & $\boldsymbol{T}_{\mathbf{1 0}}\left({ }^{\circ} \mathbf{C}\right)$ & Residual Yield (\%) \\
\hline PDPS & - & - & - & 0 \\
VMQ & 509.17 & 281.33 & 358.33 & 17.91 \\
VPMQ-1 & 496.17 & 341.67 & 416.13 & 21.29 \\
VPMQ-2 & 503.17 & 346.17 & 421.70 & 25.06 \\
VPMQ-3 & 496.17 & 363.33 & 424.74 & 29.71 \\
VPMQ-4 & 492.18 & 364.18 & 428.33 & 33.95 \\
\hline
\end{tabular}

\subsection{Thermal Properties}

The physically status of PDPS and VMQ was a viscous liquid at room temperature. VPMQ samples varied from a high viscosity liquid to a semisolid with the increase of the molar ratio of $\mathrm{Si}-\mathrm{H} / \mathrm{Si}-\mathrm{CH}=\mathrm{CH}_{2}$ from $0.2 / 1$ to $0.8 / 1$. The DSC curves in Figure 5 explain the thermal property in the range of -80 to $100{ }^{\circ} \mathrm{C}$ for all samples. A step transition but no melting peak was observed for PDPS and the VMQ polymer in the temperature range between -80 and $100{ }^{\circ} \mathrm{C}$. The DSC curves indicate that PDPS and VMQ are amorphous polymers. However, obvious exothermic peaks near about $-40^{\circ} \mathrm{C}$ can be observed in all VPMQ samples. The outset exothermic temperatures appeared at $-47.07^{\circ} \mathrm{C}$ for VPMQ-1, $-47.53^{\circ} \mathrm{C}$ for VPMQ-2, $-47.77^{\circ} \mathrm{C}$ for VPMQ-3 and $-48.29^{\circ} \mathrm{C}$ for VPMQ-4. The exothermic peaks of the four VPMQ samples appeared at $-43.69^{\circ} \mathrm{C}$ for VPMQ-1, $-43.25^{\circ} \mathrm{C}$ for VPMQ-2, $-40.73{ }^{\circ} \mathrm{C}$ for VPMQ-3 and $-40.68{ }^{\circ} \mathrm{C}$ for VPMQ-4. The values of heat enthalpy for crystallization were $12.87 \mathrm{~J} / \mathrm{g}$ for VPMQ-1, $11.56 \mathrm{~J} / \mathrm{g}$ for VPMQ-2, $6.21 \mathrm{~J} / \mathrm{g}$ for VPMQ-3 and $4.81 \mathrm{~J} / \mathrm{g}$ for VPMQ-4. The outset exothermic temperatures were in the order of VPMQ-1 > VPMQ-2 > VPMQ-3 $>$ VPMQ-4. In addition, the exothermal peak temperature of VPMQ-4 was higher than those of the other samples, but the heat enthalpy of VPMQ-4 was lowest among all the VPMQ samples. It is known that the crystallization temperature for crystalline polymers is sensitively influenced by 
prehistory and cooling [34]. Thus, it was indicated that VPMQ-4 possesses a more obvious crystalline structure. In addition, the crystallinity of the polymers is also related to the regularity of their structure. Therefore, a novel regular macromolecule structure of VPMQ polymers was probably formed through the reaction of VMQ and PDPS, and the regularity was increased gradually as the molar ratio value of $\mathrm{Si}-\mathrm{H} / \mathrm{Si}-\mathrm{CH}=\mathrm{CH}_{2}$ increased from $0.2 / 1$ to $0.8 / 1$.

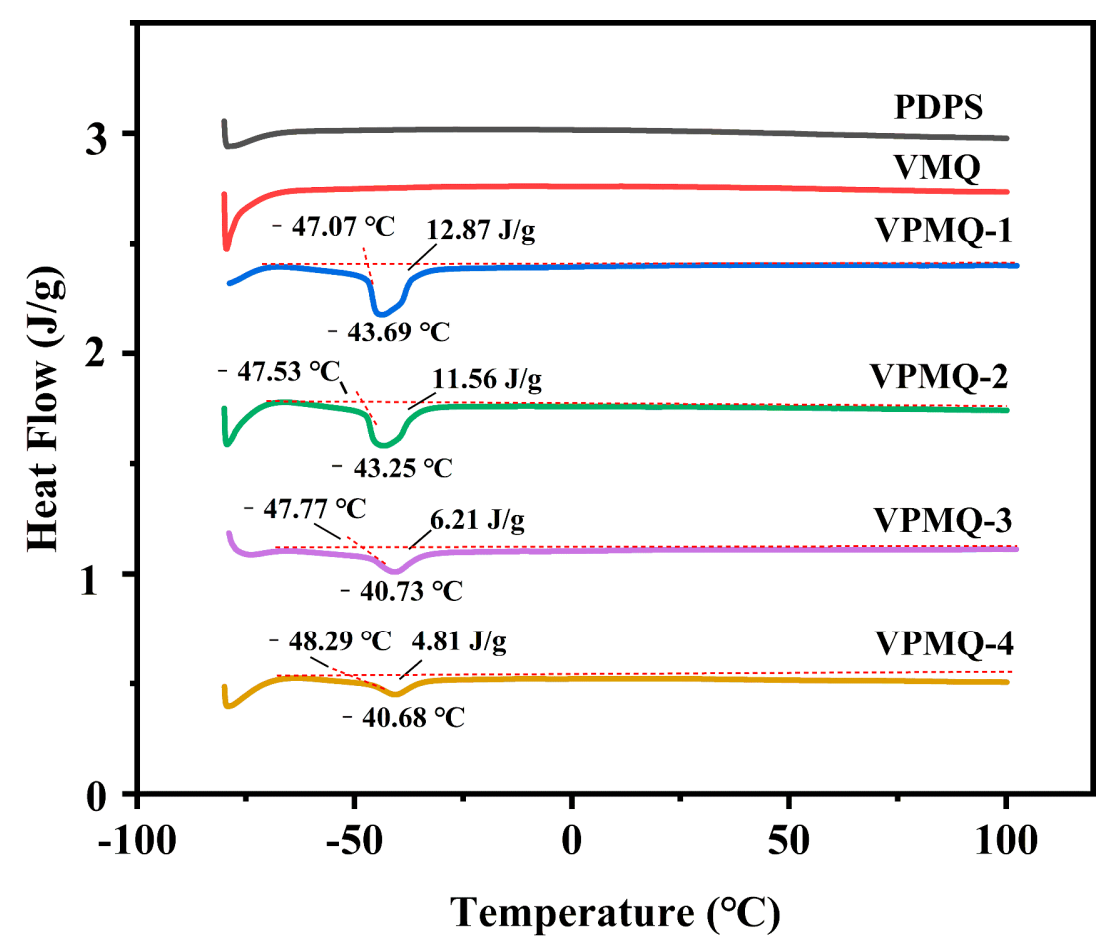

Figure 5. DSC thermograms of PDPS, VMQ and VPMQ samples with a heat rate of $10^{\circ} \mathrm{C} / \mathrm{min}$ in an $\mathrm{N}_{2}$ atmosphere.

The thermal degradation behavior of PDPS, VMQ and VPMQ samples was investigated by TGA under a nitrogen atmosphere. Their TG and DTG curves are presented in Figure 6a,b. Values of $5 \%$ and $10 \%$ mass loss $\left(T_{5}, T_{10}\right)$, the temperature of the maximum dissociation $\left(T_{\max }\right)$ and the residual yields at $800{ }^{\circ} \mathrm{C}$ are listed in Table 3. As can be seen, PDPS showed no degradation process, but evaporated completely when the temperature reached $220^{\circ} \mathrm{C}$. For VMQ and VPMQ samples, the first stage of thermal degradation at a range of $210 \sim 450^{\circ} \mathrm{C}$ is attributed to the decomposition of organic groups, such as hydroxyl, hydrocarbyl and phenyl in the polymers [35]. In this degradation process, the temperatures of 5\% and 10\% mass loss of VPMQ samples were all higher than those of $\mathrm{VMQ}$, the characteristic temperature of $5 \%$ mass loss was delayed from 281.33 to $364.18^{\circ} \mathrm{C}$, and the temperature corresponding to $10 \%$ weight loss increased from 358.33 to $428.33{ }^{\circ} \mathrm{C}$. This was probably due to the introduction of phenyl and the formation of high molecular weight polymer structures. Meanwhile, the second thermal degradation stage may be related to the fracture and rearrangement of the backbone of VMQ and VPMQ polymers in the temperature range of $450 \sim 550{ }^{\circ} \mathrm{C}$ [36]. At this stage, VPMQ samples exhibited the maximum degradation rate, which was slightly smaller than that of VMQ, and began to slightly decrease with the increase of the molar ratio of $\mathrm{Si}-\mathrm{H} / \mathrm{Si}-\mathrm{CH}=\mathrm{CH}_{2}$ (Table 3). This was attributed to the introduction of the difunctional segment of $\mathrm{Ph}_{2} \mathrm{SiO}_{2 / 2}$ (D unit), whose degradation temperature is slightly lower than that of the four functional segments of $\mathrm{SiO}_{4 / 2}(\mathrm{Q}$ units) [3]. Moreover, the residual yield at $800{ }^{\circ} \mathrm{C}$ of the VPMQ samples was obviously superior to that of the VMQ samples due to the novel macromolecular structure formed via the reaction of VMQ and linear PDPS. 

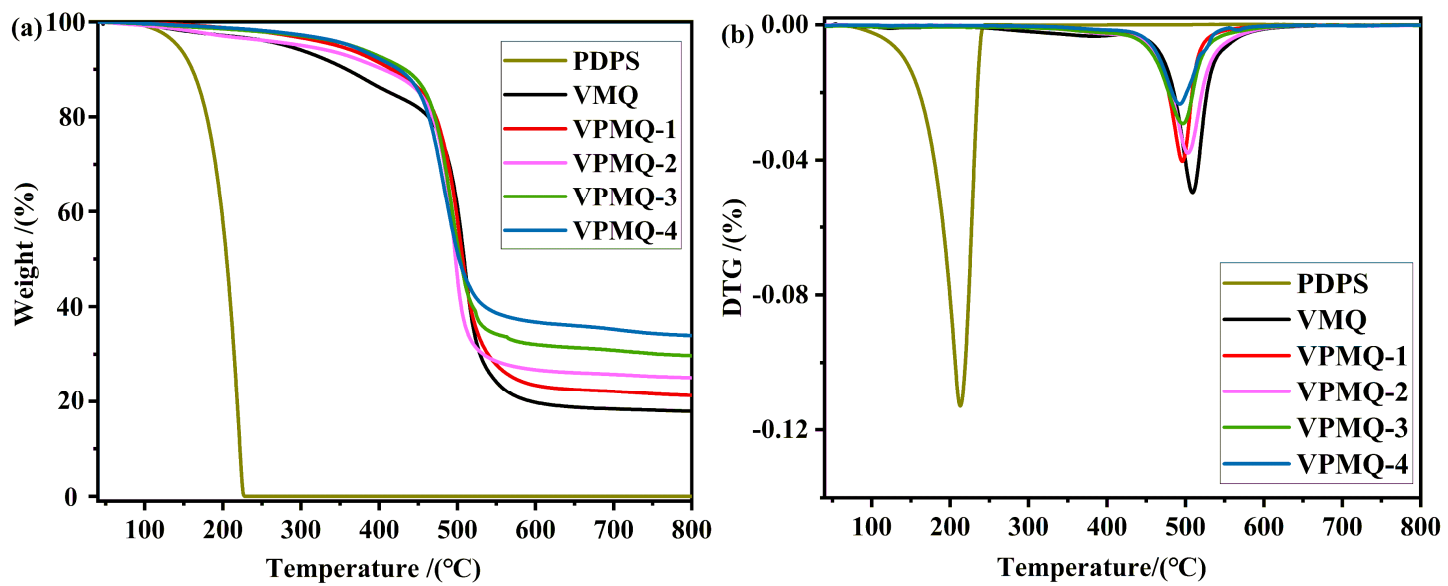

Figure 6. TG curves (a) and DTG (b) curves for VMQ and VPMQ series obtained under a nitrogen atmosphere.

\section{Conclusions}

Organic solvent-soluble high molecular weight MQ silicone polymers were prepared through the hydrosilylation reaction of VMQ and PDPS. Their weight average molecular weights were nearly $400,000 \mathrm{dal} \cdot \mathrm{mol}^{-1}$ when the molar ratio of $\mathrm{Si}-\mathrm{H} / \mathrm{Si}-\mathrm{CH}=\mathrm{CH}_{2}$ was $0.8 / 1$, and no problem of gel production appeared. These novel VPMQ polymers exhibited high thermal stability, and a higher RI than that of base VMQ silicone resin due to the formation of a regular macromolecular structure and the introduction of phenyl groups, respectively. The VPMQ polymer is expected to be useful as a potential material for fillers of high heat-resistant, optical adhesives, high-performance liquid silicone rubber and heat-resistant coatings.

Author Contributions: Conceptualization, J.J. and J.G.; Methodology, J.G.; Software, J.G.; Validation, J.J., X.G., W.L. and X.C.; Formal Analysis, J.J.; Investigation, J.J. and X.G.; Resources, J.G.; Data Curation, W.L. and X.P.; Writing-Original Draft Preparation, R.L.; Writing-Review and Editing, S.W. and J.S.; Visualization, S.W.; Supervision, J.G.; Project Administration, J.G.; Funding Acquisition, J.G.

Funding: This work was funded by the Special Funds for Applied Science and Technology Research and Development of Guangdong Province (2015B090925022), the Guangdong Public Welfare Fund and Ability Construction Project (2016A010103037), Guangdong Science and Technology Project (2016B090930010), Graduate Science, Technology Innovation Fund of Zhongkai University of Agriculture and Engineering (2018A28) and Yele Innovation Fund Project (YL201801).

Conflicts of Interest: The authors declare no conflict of interest.

\section{References}

1. Huang, Z.; Wu, J.; Liu, X.; Ji, H.; He, R.; Pimhataivoot, P.; Chen, X. Versatile cascade esterification route to MQ Resins. ACS Omega 2018, 3, 4054-4062. [CrossRef] [PubMed]

2. Ji, J.; Ge, X.; Pang, X.; Liu, R.; Wen, S.; Sun, J.; Liang, W.; Ge, J.; Chen, X. Synthesis and characterization of room temperature vulcanized silicone rubber using methoxyl-capped MQ silicone resin as self-reinforced cross-linker. Polymers 2019, 11, 1142. [CrossRef] [PubMed]

3. Li, R.; Zhang, B.; Sun, Y.; Liu, B.; Wang, G. Synthesis of Vinylphenyl Oligomeric silsesquioxane based on MQ Silicone resin. Asian J. Chem. 2013, 25, 2541-2546. [CrossRef]

4. Kuo, C.F.J; Chen, J.B.; Shih, C.Y.; Huang, C.Y. Silicone resin synthesized by tetraethoxysilane and chlorotrimethylsilane through hydrolysis-condensation reaction. J. Appl. Polym. Sci. 2014, 131, 40317. [CrossRef]

5. Kuo, A.C.M. Silicone Release Coatings for the Pressure Sensitive Industry—Overview and Trends; DC Corporation: Barry, UK, 2003; pp. 1-4.

6. Chen, W.; Zeng, X.; Lai, X.; Li, H.; Pan, Z. Effect and mechanism of ureido-modified MQ silicone resin and platinum on tracking and erosion resistance of silicone rubber. Polym. Test. 2018, 70, 162-169. [CrossRef] 
7. Lee, B.K.; Ryu, J.H.; Baek, I.B.; Kim, Y.; Jang, W.I.; Kim, S.H.; Yoon, Y.S.; Kim, S.H.; Hong, S.G.; Byun, S.; et al. Silicone-based adhesives with highly tunable adhesion force for Skin-contact applications. Adv. Healthc. Mater. 2017, 6, 1700621. [CrossRef]

8. Yilgör, E.; Yilgör, I. Silicone containing copolymers: synthesis, properties and applications. Prog. Polym. Sci. 2014, 39, 1165-1195. [CrossRef]

9. Wu, T.; Lai, X.; Liu, F.; Zeng, X. Efficiently enhancing the tracking and erosion resistance of silicone rubber by the synergism of fluorine-containing polyphenyl silsesquioxane and ureido-containing MQ silicone resin. Appl. Surf. Sci. 2018, 459, 483-491. [CrossRef]

10. Peng, D.; Mu, Q.H.; Zhang, S.; Li, S.; Wang, F. Synthesis and Properties of Phenyl Silicone Resin Reinforced Addition Type Liquid Phenyl Silicone Rubber. Mater. Sci. Forum. 2018, 926, 39-44. [CrossRef]

11. Jia, P.; Liu, H.; Liu, Q.; Cai, X. Thermal degradation mechanism and flame retardancy of MQ silicone/epoxy resin composites. Polym. Degrad. Stabil. 2016, 134, 144-150. [CrossRef]

12. Roberts, C.; Cosgrove, T.; Schmidt, R.G.; Gordon, G.V. Diffusion of poly (dimethyl-siloxane) mixtures with silicate nanopartic les. Macromolecules 2001, 34, 538-543. [CrossRef]

13. Kaneko, Y.; Coughlin, E.B.; Gunji, T.; Itoh, M.; Matsukawa, K.; Naka, K. Silse- squioxanes: Recent advancement and novel applications. Int. J. Polym. Sci. 2012, 2012, 453821.

14. Robeyns, C.; Picard, L.; Ganachaud, F. Synthesis, characterization and modification of silicone resins: An "Augmented Review". Prog. Org. Coat. 2018, 125, 287-315. [CrossRef]

15. Elena, T.; Nataliya, V.; Aziz, M. Synthesis and Properties of MQ Copolymers: Current State of Knowledge. Molecules 2017, 22, 1768. [CrossRef]

16. Huang, W.; Huang, Y.; Yu, Y. Synthesis of MQ silicone resins through hydrol ytic condensation of ethyl polysilicate and hexamethyldisiloxane. J. Appl. Polym. Sci. 1998, 70, 1753-1757. [CrossRef]

17. Xu, X.; Wu, C.; Zhang, B.; Dong, H. Preparation, structure characterization, and thermal performance of phenyl-modified MQ silicone resins. J. Appl. Polym. Sci. 2013, 128, 4189-4200. [CrossRef]

18. Flagg, D.H.; McCarthy, T.J. Rediscovering silicones: MQ copolymers. Macromolecules 2016, 49, 8581-8592. [CrossRef]

19. Pan, K.; Zeng, X.; Li, H.; Liao, F.; Zhang, H.L.; Yin, C.Y. Synthesis of phenyl silicone resin with epoxy and acrylate group and its adhesion enhancement for addition-cure silicone encapsulant with high refractive index. J. Adhes. Sci. Technol. 2016, 30, 2699-2709. [CrossRef]

20. Xiang, H.; Ge, J.; Cheng, S. Synthesis and characterization of titania/MQ silicone resin hybrid nanocomposite via sol-gel process. J. Sol-Gel Sci. Technol. 2011, 59, 635. [CrossRef]

21. Xie, C.; Zeng, X.; Fang, W.; Lai, X.; Li, H. Effect of alkyl-disubstituted ureido silanes with different alkyl chain structures on tracking resistance property of addition-cure liquid silicone rubber. Polym. Degrad. Stabil. 2017, 142, 263-272. [CrossRef]

22. Xie, H.; Hu, W.; Wu, Z.; Hu, G.; Zhu, G.; Liu, Q.; Jia, Z. Study on synthesizing MQ silicone with solid acid as catalyst and its properties. China Adhes. 2016, 25, 308-316. (In Chinese)

23. Wada, T.; Itoh, K. Heat-Curable Elastomeric Silicone Compositions. U.S. Patent 3,652,475, 28 March 1972.

24. Li, B.; Zhang, Z.; Ma, D.; Cai, Q.; Feng, S.; Zhang, J. Preparation and kinetic analysis of room-temperature vulcanized methylethylsilicone rubbers. J. Appl. Polym. Sci. 2015, 132, 42656. [CrossRef]

25. Choi, S.S.; Lee, A.S.; Lee, H.S.; Jeon, H.Y.; Baek, K.Y.; Choi, D.H.; Hwang, S.S. Synthesis and chara- cterization of UV-curable ladder-like polysilsesquioxane. J. Polym. Sci. A Polym. Chem. 2011, 49, 5012-5018. [CrossRef]

26. Chang, S.; Matsumoto, T.; Matsumoto, H.; Unno, M. Synthesis and characterization of heptacyclic laddersiloxanes and ladder polysilsesquioxane. Appl. Organomet. Chem. 2010, 24, 241-246. [CrossRef]

27. Chen, J.; Fu, Z.; Huang, H.; Zeng, X.; Chen, Z. Preparation and properties of vinylphenyl-silicone resins and their application in LED packaging. RSC Adv. 2016, 6, 71924-71933. [CrossRef]

28. Witteman, L.; Evers, T.; Shu, Z. Hydrosilylation in Aryliminopyrrolide Substituted Silanes. Chem. Eur. J. 2016, 22, 6087-6099. [CrossRef]

29. Antosik, A.K.; Czech, Z. Pressure-Sensitive Adhesives (PSA) Based on Silicone. Adv. Mater. Interfaces 2016, 7, 249-274.

30. Ji, J.; Ge, X.; Liang, W.; Liang, R.; Pang, X.; Liu, R.; Wen, S.; Sun, J.; Chen, X.; Ge, J. A Simple Preparation Route for Bio-Phenol MQ Silicone Resin via the Hydrosilylation Method and its Autonomic Antibacterial Property. Polymers 2019, 11, 1389. [CrossRef] 
31. Wei, Q.; Zan, X.; Qiu, X.; Öktem, G.; Sahre, K.; Kiriy, A.; Voit, B. High Refract ive Index Hyperbranched Polymers Prepared by Two Naphthalene-Bearing Monomers via Thiol-Yne Reaction. Macromol. Chem. Phys. 2016, 217, 1977-1984. [CrossRef]

32. Yang, S.; Kim, J.; Jin, J.; Kwak, S.; Bae, B. Cycloaliphatic epoxy oligosiloxane-derived hybrid materials for a high-refractive index LED encapsulant. J. Appl. Polym. Sci. 2011, 122, 2478-2485. [CrossRef]

33. Atkins, G.R.; Krolikowska, R.M.; Samoc, A. Optical properties of an ormosil system comprising methyl and phenyl substituted silica. J. Non-Cryst. Solids 2000, 265, 210-220. [CrossRef]

34. Takahashi, T.; Kaschta, J.; Münstedt, H. Melt rheology and structure of silicone resins. Rheol. Acta 2001, 40, 490-498. [CrossRef]

35. Deshpande, G.; Rezac, M.E. Kinetic aspects of the thermal degradation of poly (dimethyl siloxane) and poly (dimethyl diphenyl siloxane). Polym. Degrad Stabil. 2002, 76, 17-24. [CrossRef]

36. Pham, Q.T.; Chern, C.S. Thermal stability of organofunctional polysiloxanes. Thermochim. Acta 2013, 565, 114-123. [CrossRef]

(C) 2019 by the authors. Licensee MDPI, Basel, Switzerland. This article is an open access article distributed under the terms and conditions of the Creative Commons Attribution (CC BY) license (http://creativecommons.org/licenses/by/4.0/). 